[Article]

\title{
过充电保护添加剂1,4-二甲氧基苯的反应机理
}

\author{
李田田 ${ }^{1}$ 王朝阳 ${ }^{1}$ 邢丽丹 ${ }^{1}$ 李伟善 ${ }^{1,2,3, *}$ 彭 涁 ${ }^{1}$ 许梦清 ${ }^{1,2,3}$ \\ 顾凤龙 ${ }^{1,2,3}$ 胡社军 ${ }^{1,2,3}$
}

('华南师范大学化学与环境学院, 广州 510006; 2华南师范大学, 广东高校电化学储能与发电技术重点实验室, 广州 510006;

3 华南师范大学, 电化学储能材料与技术教育部工程研究中心, 广州 510006)

摘要: 采用密度泛函理论(B3LYP/6-311+G $(d, p)$ )和MP2/6-311+G $(d, p)$ 方法, 研究锂离子电池过充电保护添加 剂1,4-二甲氧基苯( $p$-DMOB)的作用机理. 计算结果表明, 在过充时, $p$-DMOB 优先于溶剂分子(乙基甲基碳酸 酯、二甲基碳酸酯、碳酸乙酯)发生氧化反应. 用 B $3 L Y P$ 和 MP2 计算所得的 $p$-DMOB 理论氧化电位接近, 分别为 4.12 和 $4.05 \mathrm{~V}\left(v s \mathrm{Li} / \mathrm{Li}^{+}\right)$. $p$-DMOB氧化时首先失去一个电子, 生成 $p-\mathrm{DMOB}^{+*}$ 正离子自由基, 用 B3LYP和 MP2 方法计算所得的相应能量变化分别为 701.24 和 $728.27 \mathrm{~kJ} \cdot \mathrm{mol}^{-1}$. 失去电子后苯环的共轨性受到破坏, 随后 $p-\mathrm{DMOB}^{+*}$ 苯环上的 $\mathrm{C}-\mathrm{H}$ 键发生断裂, 失去 $\mathrm{H}^{+}$并形成 $p-\mathrm{DMOB}$ - 自由基. 用 B3LYP 和 MP2 方法计算所得的相 应能量变化分别为 1349.78 和 $1810.99 \mathrm{~kJ} \cdot \mathrm{mol}^{-1}$. $p$-DMOB · 自由基很不稳定, 会在电极表面发生聚合反应形成 聚合物膜, 用 B3LYP和 MP2 方法计算所得的相应能量变化分别为 -553.37 和 $-1331.20 \mathrm{~kJ} \cdot \mathrm{mol}^{-1}$.

关键词：锂离子电池；过充电保护添加剂；1,4-二甲氧基苯； 反应机理；密度泛函理论

中图分类号: 0646

\section{Reaction Mechanism of 1,4-Dimethoxy Benzene as an Overcharge Protection Additive}
LI Tian-Tian ${ }^{1}$
WANG Chao-Yang
XING Li-Dan ${ }^{1}$
XU Meng-Qing ${ }^{1,2,3}$
GU Feng-Long ${ }^{1,2,3}$
LI Wei-Shan ${ }^{1,2,3, *}$
HU She-Jun ${ }^{1,2,3}$
PENG Bin ${ }^{1}$

('School of Chemistry and Environment, South China Normal University, Guangzhou 510006, P. R. China; ${ }^{2}$ Key Laboratory of Electrochemical Technology on Energy Storage and Power Generation of Guangdong Higher Education Institutes, South China Normal University, Guangzhou 510006, P. R. China; ${ }^{3}$ Engineering Research Center of Materials and Technology for Electrochemical Energy Storage (Ministry of Education), South China Normal University, Guangzhou 510006, P. R. China)

\begin{abstract}
The reaction mechanism of 1,4-dimethoxybenzene ( $p$-DMOB) as an overcharge protection additive for lithium ion batteries was determined by theoretical calculation of density functional theory (DFT) at the level of B3LYP/6-311+G(d,p) and MP2/6-311+G(d,p). It was found that $p$-DMOB is oxidized prior to the solvents, ethyl methyl carbonate, dimethyl carbonate, and ethylene carbonate, when the lithium ion battery is overcharged. The calculated oxidative potentials of $p$-DMOB by B3LYP and MP2 methods are well in agreement at 4.12 and $4.05 \mathrm{~V}\left(v s \mathrm{Li} / \mathrm{Li}^{+}\right)$, respectively. The initial oxidation of $p$-DMOB involves a one-electron transfer resulting in a radical cation $p$-DMOB ${ }^{+}$. The corresponding energy variations were 701.24 and $728.27 \mathrm{~kJ} \cdot \mathrm{mol}^{-1}$ from B3LYP and MP2 calculations, respectively. The $p$-DMOB ${ }^{+\cdot}$ species then loses one proton forming a radical $p$-DMOB - through the breaking of a $\mathrm{C}-\mathrm{H}$ bond on the benzene ring, with the corresponding energy variations of 1349.78 and $1810.99 \mathrm{~kJ} \cdot \mathrm{mol}^{-1}$ for B3LYP and MP2, respectively. The $p$-DMOB - species is unstable and copolymerizes forming an insulated polymer with the
\end{abstract}

Received: October 31, 2011; Revised: January 3, 2012; Published on Web: January 13, 2012.

"Corresponding author. Email: liwsh@scnu.edu.cn; Tel/Fax: +86-20-39310256.

The project was supported by the Joint Project of National Natural Science Foundation of China and Natural Science Foundation of Guangdong Province (U1134002) and Natural Science Foundation of Guangdong Province, China (10351063101000001).

国家自然科学基金-广东省人民政府自然科学联合基金(U1134002)和广东省自然科学基金(10351063101000001)资助项目

(C) Editorial office of Acta Physico-Chimica Sinica 
corresponding energy variations of -553.37 and $-1331.20 \mathrm{~kJ} \cdot \mathrm{mol}^{-1}$ for B3LYP and MP2, respectively.

Key Words: Lithium ion battery; Overcharge protection additive; 1,4-Dimethoxy benzene; Reaction mechanism; Density functional theory

\section{Introduction}

Lithium ion battery (LIB) has been widely used to power portable electronic devices such as camera, mobile phone, and computer. It is also demonstrated to be promising for largescale applications such as hybrid or pure electric vehicles. ${ }^{1-6}$ One of the important limitations for the application of LIB is safety concern. ${ }^{7,8}$ It is well known that solvents in LIB tend to decompose on anode or cathode surface when LIB is overcharged, ${ }^{9-12}$ and LIB becomes thermally unstable at overcharged state, which sometimes smokes, ignites, and even explodes. ${ }^{13,14}$ Much effort has been devoted to improving the safety characteristics of LIB in recent years. The use of solid polymer or ionic liquid electrolytes provides a safe solution to the decomposition of solvents that have been used in commercial LIBs, but the ionic conductivity of these electrolytes is too low to be used in practice. Alternatively, various types of electrolyte additives, such as polymerizable compounds, have been proposed as additives in electrolyte to prevent the LIBs from overcharging. ${ }^{15,16}$ Polymerizable compounds, also called "shutdown additives", are found to be effective for the overcharge protection of LIB. These additives are electrochemically polymerized forming an insulating polymer layer that blocks charge current from flowing further when the LIB is overcharged.

It has been reported by several research groups that many derivatives based on 1,4-dimethoxy benzene ( $p$-DMOB), the compounds in which the hydrogen atoms on the benzene ring of $p$-DMOB are replaced by electron-donating or electron-withdrawing groups, are functioned as redox shuttles for overcharge protection of LIB. ${ }^{17-21} \mathrm{~A}$ LIB is protected from overcharge by a redox shuttle through the reduction of oxidized shuttle on anode and the oxidation of reduced shuttle on cathode of LIB. The reaction process for the $p$-DMOB based derivatives as redox shuttles has been understood through the theoretical calculations. ${ }^{22}$ Different from its derivatives, however, $p$-DMOB was found to function as a shutdown additive. ${ }^{23}$ The aim of this paper is to understand the reaction mechanism of $p$-DMOB as a shutdown additive for lithium ion battery.

\section{Computational details}

All calculations have been performed using Gaussian 03 package. ${ }^{24}$ The geometries are optimized by the B3LYP and MP2 methods in conjunction with the $6-311+\mathrm{G}(d, p)$ basis set. ${ }^{25,26}$ The solvent effects are considered by employing the integral equation formalism of the polarizable continuum model (IEFPCM) ${ }^{27} \mathrm{~A}$ dielectric constant of 31.3 is adopted, which is a weighted average value between the dielectric constants of ethylene carbonate (EC: 89), dimethyl carbonate (DMC: 3), and ethylmethyl carbonate (EMC: 2$)\left(n_{\mathrm{EC}} / n_{\mathrm{DMC}} / n_{\mathrm{EMC}}=1: 1: 1\right)$. To confirm each optimized stationary point and make zero-point energy (ZPE) corrections, frequency analyses are done with the same basis set. Enthalpy and Gibbs free energy are obtained at $298.2 \mathrm{~K}$. Charge distribution is analyzed by the natural bond orbital (NBO) theory.

The absolute potential $\left(\varphi_{\mathrm{abs}}\right)$ for the oxidation of $p$-DMOB is obtained based on the following equation: ${ }^{28}$

$$
\begin{gathered}
\varphi_{\text {abs }}(p-\mathrm{DMOB})=\mathrm{IP}+\left[-T \Delta S+\Delta G_{\mathrm{s}}^{0}\left(p-\mathrm{DMOB}^{+*}\right)-\right. \\
\left.\Delta G_{\mathrm{s}}^{0}(p-\mathrm{DMOB})\right] / F
\end{gathered}
$$

where IP is ionization potential, $\Delta S$ is the entropy difference between $p$-DMOB and $p$-DMOB ${ }^{+}$in gas phase, $\Delta G_{\mathrm{S}}^{0}$ is the Gibbs free energy change of $p$-DMOB or $p$-DMOB ${ }^{+}$between gas phase and solvent, and $F$ is Faraday constant. The oxidation potential, $\varphi(p$-DMOB), of the compounds in this paper is given with respect to $\varphi_{\text {abs }}\left(\mathrm{Li}_{/} / \mathrm{Li}^{+}\right)$that is the absolute potential of $\mathrm{Li} /$ $\mathrm{Li}^{+}(1.4 \mathrm{~V})$.

\section{Results and discussion}

\subsection{Oxidation activity and oxidative potential}

The optimized geometric structures of $p$-DMOB, ethyl methyl carbonate, dimethyl carbonate, ethylene carbonate, and their radical cations are presented in Fig.1.

Table 1 lists the frontier molecular orbital energy and ionization potential (IP) of $p$-DMOB and solvents in gas phase, optimized by B3LYP and MP2. On the basis of the molecular orbital theory, the ability of a molecule to lose one electron depends on the energy level of the highest occupied molecular orbital (HOMO). There exists difference in calculated values of HOMO or IP between B3LYP and MP2, but the same conclusion on the difference among $p$-DMOB, EMC, DMC, and $\mathrm{EC}$ can be drawn from these two methods, i.e., $p$-DMOB is oxidized prior to the solvents. The preferable reduction oxidation of $p$-DMOB is important for $p$-DMOB to be used as a shutdown additive.

Table 2 lists the thermodynamic properties of $p$-DMOB and its radical cation $\left(p-\mathrm{DMOB}^{+\bullet}\right)$ in gas phase $(\mathrm{g})$ and solvent $(\mathrm{s})$. With these data, we can obtain the theoretical oxidation potential $\left(E_{\text {cal }}\right)$ of $p$-DMOB, which is $4.12 \mathrm{~V}\left(v s \mathrm{Li} / \mathrm{Li}^{+}\right)$by B3LYP and $4.05 \mathrm{~V}\left(v_{s} \mathrm{Li} / \mathrm{Li}^{+}\right)$by MP2, respectively. Both theoretical values are in good agreement with the experimentally obtained oxidation potential, which is $3.9 \mathrm{~V}\left(v s \mathrm{Li} / \mathrm{Li}^{+}\right){ }^{20}$

\subsection{Oxidative process of $\boldsymbol{p}$-DMOB}

The initial oxidation of $p$-DMOB involves a one-electron transfer, resulting in radical cation $\left(p-\mathrm{DMOB}^{+}\right)$. The optimized geometry is presented in Fig.1. The charge distributions on atoms in $p$-DMOB and $p$-DMOB ${ }^{+}$obtained by natural popula- 


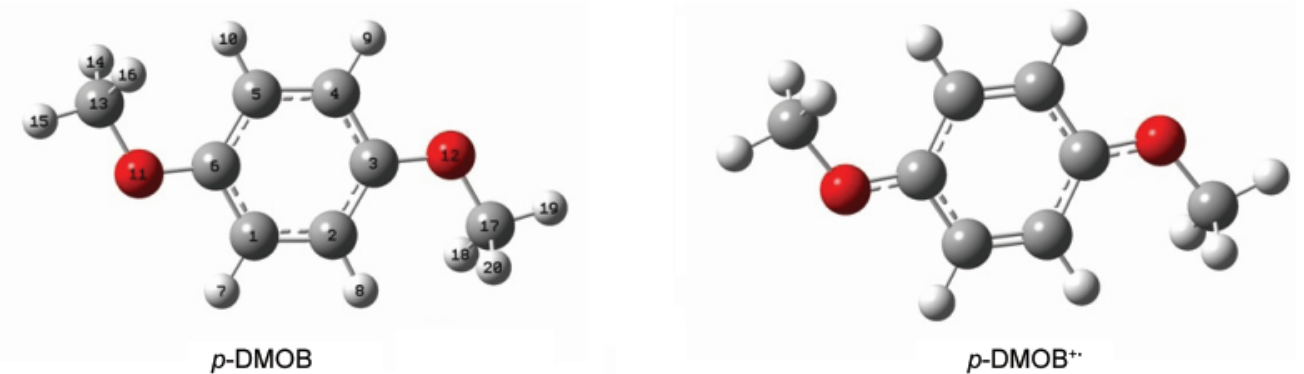

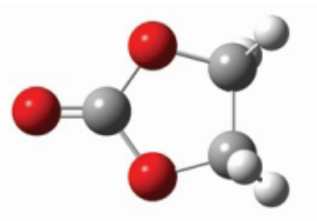

EC

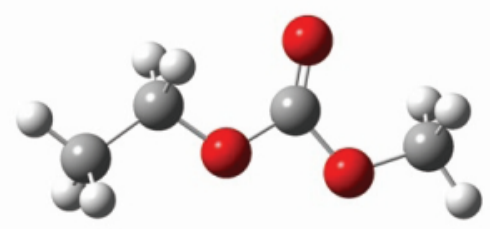

$\mathrm{EMC}^{+\cdot}$

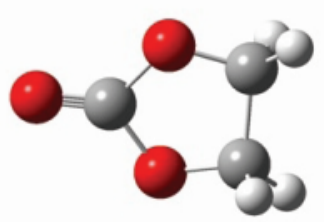

$\mathrm{EC}^{+*}$

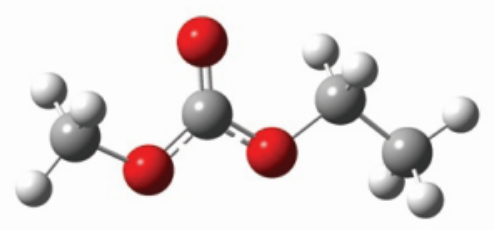

EMC

Fig.1 Optimized geometric structures of $p$-DMOB, EMC, DMC, EC and their radical cations

Table 1 The frontier molecular orbital energy and IP of $p$-DMOB and solvents in gas phase

\begin{tabular}{|c|c|c|c|c|c|c|}
\hline & \multicolumn{2}{|c|}{$E_{\text {номо }} / \mathrm{eV}$} & \multicolumn{2}{|c|}{$E_{\text {Lumo }} / \mathrm{eV}$} & \multicolumn{2}{|c|}{$\mathrm{IP} /\left(\mathrm{kJ} \cdot \mathrm{mol}^{-1}\right)$} \\
\hline & B3LYP & MP2 & B3LYP & MP2 & B3LYP & MP2 \\
\hline$p$-DMOB & -5.64 & -7.94 & -0.66 & 0.76 & 701.24 & 728.27 \\
\hline EMC & -8.11 & -12.77 & -0.10 & 0.92 & 990.65 & 1047.88 \\
\hline $\mathrm{DMC}$ & -8.21 & -12.85 & 0.02 & 2.59 & 1005.46 & 1063.41 \\
\hline $\mathrm{EC}$ & -8.45 & -12.87 & -0.45 & 1.50 & 1024.45 & 1083.41 \\
\hline
\end{tabular}

tion analysis (NPA) are presented in Table 3. It can be seen from Table 3 that the charge distributions on atoms in $p$-DMOB and $p$-DMOB ${ }^{+\bullet}$ are quite different. The charge changes on $-\mathrm{C}_{6} \mathrm{H}_{4},-\mathrm{O}^{11} \mathrm{CH}_{3},-\mathrm{O}^{12} \mathrm{CH}_{3}$ are $-0.589 e,-0.205 e,-0.205 e$ by $\mathrm{B} 3 \mathrm{LYP}$ and $-0.687 e,-0.154 e,-0.155 e$ by MP2, respectively. The results obtained by both B3LYP and MP2 indicate that the electron mainly bereaves from benzene ring and the charge conjugation of benzene ring is damaged after the initial oxidation of $p$-DMOB.

Scheme 1 shows the possible pathways for the further oxidation. The $p$-DMOB ${ }^{+}$loses a hydrogen ion forming a radical $p$-DMOB - with the cleavage of the $\mathrm{C}^{1}-\mathrm{H}^{7}$ bond and $p$-DMOB . copolymerizes by itself forming a polymer. The $\Delta E_{1}, \Delta E_{2}$, and $\Delta E_{3}$ are defined as the activation energies in the reactions $p$-DMOB-e $\rightarrow p$-DMOB ${ }^{+}, p$-DMOB ${ }^{+}-\mathrm{H}^{+} \rightarrow p$-DMOB $\cdot$, and $p$ $\mathrm{DMOB} \cdot+p$-DMOB $\rightarrow p$-DMOB- 1 , respectively. The optimized geometry structures of $p$-DMOB and $p$-DMOB ${ }^{+}$are shown in Fig.1, and the optimized geometry structures of $p$-DMOB $\cdot$ and p-DMOB-1 are presented in Fig.2.

The energies of compounds involved in the polymerization of $p$-DMOB are presented in Table 4 . The energy variation of $p$-DMOB ${ }^{+\bullet}$ with the bond length of $\mathrm{C}^{1}-\mathrm{H}^{7}$ is shown in Fig.3. It can be found from Fig. 3 that the energy of $p$-DMOB ${ }^{+}$increases with increasing the bond length. This suggests that there is no transition state available during the breaking of $\mathrm{C}^{1}-\mathrm{C}^{7}$ bond. The obtained $\Delta E_{1}, \Delta E_{2}, \Delta E_{3}$ values are $701.24,1349.78,-553.37 \mathrm{~kJ} \cdot \mathrm{mol}^{-1}$ by B3LYP and $728.27,1810.99,-1331.20 \mathrm{~kJ} \cdot \mathrm{mol}^{-1}$ by MP2, respectively. Although $\Delta E_{2}$ is large, the sum of $\Delta E_{2}$ and $\Delta E_{3}$ is small, compared with $\Delta E_{1}$. Therefore, the polymerization is preferable and $p$-DMOB ${ }^{+}$functions as a shutdown additive for the overcharge protection of LIB.

From the obtained results above, it can be concluded that $p$-DMOB is preferably to be oxidized forming a polymer

Table 2 Thermodynamic properties of $p$-DMOB and its radical cation ( $p$-DMOB $\left.{ }^{+\bullet}\right)$ in gas phase (g) and solvent (s)

\begin{tabular}{cccccc}
\hline & Method & $S_{\mathrm{g}} /\left(\mathrm{J} \cdot \mathrm{mol}^{-1} \cdot \mathrm{K}^{-1}\right)$ & $G_{g} /$ hartree & $G_{s} /$ hartree & $E_{\mathrm{s}} /$ hartree \\
\hline$p$-DMOB & B3LYP & 400.320936 & -461.291515 & -461.301551 & -461.421082 \\
& MP2 & 409.354192 & -459.971393 & -459.986624 & -460.099715 \\
$p$-DMOB & B3LYP & 406.228744 & -461.024229 & -461.097394 & -461.421082 \\
& MP2 & 413.554928 & -459.686732 & -459.786732 & -459.822332 \\
\hline
\end{tabular}


Table 3 Charge distribution (e) on atoms in $p$-DMOB and $p_{-D M O B}{ }^{+\bullet}$ obtained by natural population analysis

\begin{tabular}{|c|c|c|c|c|c|c|}
\hline \multirow{2}{*}{ Atom } & \multicolumn{2}{|c|}{$p$-DMOB } & \multicolumn{2}{|c|}{$p$-DMOB ${ }^{+}$} & \multicolumn{2}{|c|}{ Change } \\
\hline & B3LYP & MP2 & B3LYP & MP2 & B3LYP & MP2 \\
\hline $\mathrm{C}^{1}$ & -0.223 & -0.213 & -0.156 & -0.131 & -0.067 & -0.082 \\
\hline $\mathrm{C}^{2}$ & -0.272 & -0.262 & -0.243 & -0.263 & -0.029 & 0.001 \\
\hline $\mathrm{C}^{3}$ & 0.294 & 0.337 & 0.426 & 0.527 & -0.132 & -0.190 \\
\hline $\mathrm{C}^{4}$ & -0.223 & -0.213 & -0.156 & -0.131 & -0.067 & -0.082 \\
\hline $\mathrm{C}^{5}$ & -0.272 & -0.263 & -0.242 & -0.263 & -0.030 & 0.000 \\
\hline $\mathrm{C}^{6}$ & 0.294 & 0.337 & 0.426 & 0.527 & -0.132 & -0.190 \\
\hline $\mathrm{H}^{7}$ & 0.218 & 0.209 & 0.252 & 0.246 & -0.034 & -0.037 \\
\hline $\mathrm{H}^{8}$ & 0.212 & 0.203 & 0.244 & 0.238 & -0.032 & -0.035 \\
\hline $\mathrm{H}^{9}$ & 0.218 & 0.209 & 0.252 & 0.246 & -0.034 & -0.037 \\
\hline $\mathrm{H}^{10}$ & 0.212 & 0.203 & 0.244 & 0.238 & -0.032 & -0.035 \\
\hline $\mathrm{O}^{11}$ & -0.548 & -0.620 & -0.427 & -0.547 & -0.121 & -0.073 \\
\hline $\mathrm{O}^{12}$ & -0.548 & -0.620 & -0.427 & -0.547 & -0.121 & -0.073 \\
\hline $\mathrm{C}^{13}$ & -0.207 & -0.104 & -0.220 & -0.114 & 0.013 & 0.010 \\
\hline $\mathrm{H}^{14}$ & 0.168 & 0.143 & 0.200 & 0.171 & -0.032 & -0.028 \\
\hline $\mathrm{H}^{15}$ & 0.191 & 0.166 & 0.224 & 0.201 & -0.033 & -0.035 \\
\hline $\mathrm{H}^{16}$ & 0.168 & 0.143 & 0.200 & 0.171 & -0.032 & -0.028 \\
\hline $\mathrm{C}^{17}$ & -0.207 & -0.104 & -0.220 & -0.114 & 0.013 & 0.010 \\
\hline $\mathrm{H}^{18}$ & 0.168 & 0.143 & 0.200 & 0.171 & -0.032 & -0.028 \\
\hline $\mathrm{H}^{19}$ & 0.191 & 0.166 & 0.224 & 0.202 & -0.033 & -0.036 \\
\hline $\mathrm{H}^{20}$ & 0.168 & 0.143 & 0.200 & 0.171 & -0.032 & -0.028 \\
\hline
\end{tabular}

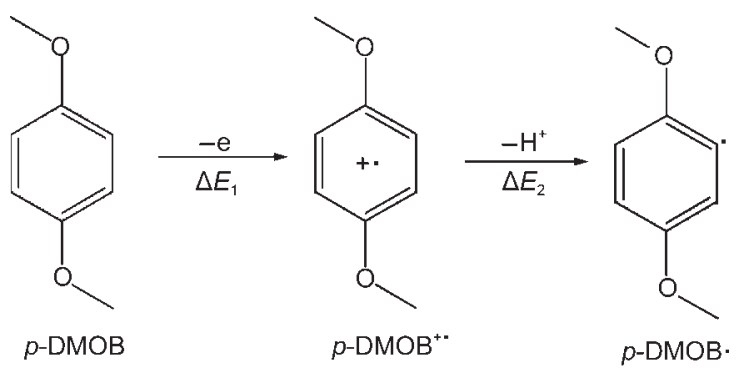<smiles>COc1ccc(OC)c(-c2cc(OC(=O)COc3cc(OCC(C)(C)C)ccc3OC)ccc2OC)c1</smiles>

Scheme 1 Reaction pathways for the polymerization mechanism of $p$-DMOB

through the breaking of $\mathrm{C}-\mathrm{H}$ bond on benzene ring. Differently, the $\mathrm{C}-\mathrm{H}$ bond on benzene ring in the radical cations formed from the one-electron oxidation of $p$-DMOB derivatives cannot be broken. Since the radical cations of $p$-DMOB derivatives are hard to oxidize further, they are preferably reduced on anode and turn back to the derivative molecules. ${ }^{22}$ This is why $p$-DMOB functions as a shutdown additive but its derivatives as shuttle additives.
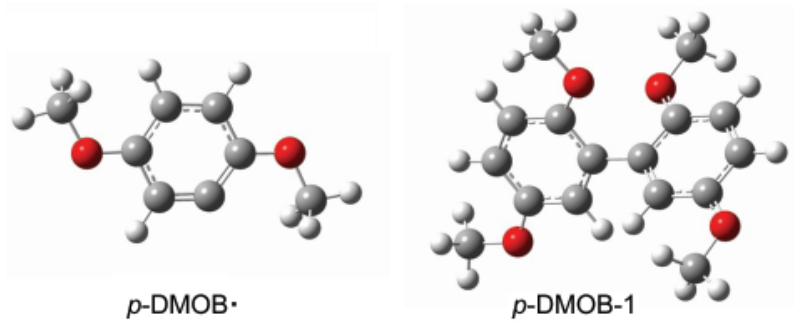

Fig.2 Optimized geometry structures of $p$-DMOB · and p-DMOB-1

Table 4 Energy of compounds involved in the polymerization of $p$-DMOB

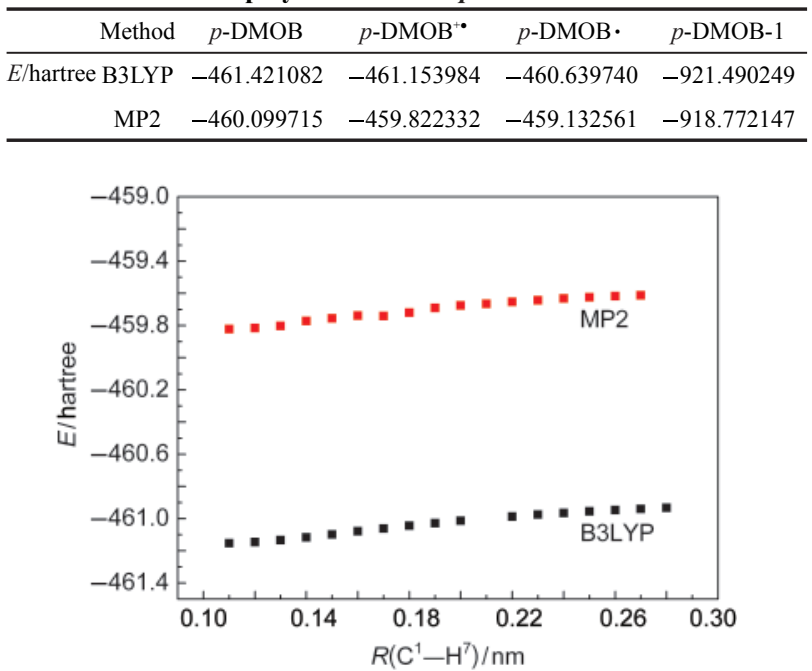

Fig.3 Energy variation of $p-\mathrm{DMOB}^{+\bullet}$ with the bond lengths of $\mathrm{C}^{1}-\mathrm{H}^{7}$

\section{Conclusions}

The reaction mechanism of $p$-DMOB as an overcharge protection additive for lithium ion battery was understood with the calculation based on B3LYP/6-311+ G( $d, p)$ and MP2/6-311+ $\mathrm{G}(d, p)$. Based on the calculated results, $p$-DMOB is oxidized prior to the solvents when the battery is overcharged. The initial oxidation of $p$-DMOB involves a one-electron transfer from $p$-DMOB resulting in a radical cation $p$-DMOB ${ }^{+}$, the corresponding energy is $701.24 \mathrm{~kJ} \cdot \mathrm{mol}^{-1}$ by B3LYP and 728.27 $\mathrm{kJ} \cdot \mathrm{mol}^{-1}$ by MP2. The radical cation loses a hydrogen ion forming the radical $p$-DMOB $\cdot$ with the cleavage of the $\mathrm{C}-\mathrm{H}$ bond on benzene ring and $p$-DMOB - copolymerizes forming a polymer.

\section{References}

(1) Ménard, L.; Fontès, G.; Astier, S. Energy Convers. Manage. 2010, 327.

(2) Yu, Y.; Gu, L.; Zhu, C.; Aken, P. A.; Maier, J. J. Am. Chem. Soc. 2009, 131, 15984.

(3) Yao, Z. D.; Wei, W.; Wang, J. L.; Yang, J.; Nuli, Y. N. Acta Phys. -Chim. Sin. 2011, 27, 1005. [姚真东, 魏 巍, 王久林, 杨 军, 努丽燕娜. 物理化学学报, 2011, 27, 1005.]

(4) Fergus, J. W. J. Power Sources 2010, 195, 939. 
(5) Xu. J.; Yao, W. H.; Yao, Y. W.; Wang, Z. C.; Yang, Y. Acta Phys. -Chim. Sin. 2009, 25, 201. [许 杰, 姚万浩, 姚宜稳, 王周成, 杨 勇. 物理化学学报, 2009, 25, 201.]

(6) Xu, M. Q.; Zuo, X. X.; Li, W. S.; Zhou, H. J.; Liu, J. S.; Yuan, Z. Z. Acta Phys. -Chim. Sin. 2006, 22, 335. [许梦清, 左晓希, 李伟善, 周豪杰, 刘建生, 袁中直. 物理化学学报, 2006, 22, 335.]

(7) Feng, J. K.; Ai, X. P.; Cao, Y. L.; Yang, H. X. Electrochem. Commun. 2007, 9, 25.

(8) Chung, Y. S.; Yoo, S. H.; Kim, C. K. Ind. Eng. Chem. Res. 2009, $48,4346$.

(9) Matsuta, S.; Kato, Y.; Ota, T.; Kurokawa, H.; Yoshimura, S.; Fujitani, S. J. Electrochem. Soc. 2001, 148, A7.

(10) Moshkovich, M.; Cojocaru, M.; Gottlieb, H. E.; Aurbach, D. J. Electroanal. Chem. 2001, 497, 84.

(11) Xing, L. D.; Wang, C. Y.; Li, W. S.; Xu, M. Q.; Meng, X. L.; Zhao, S. F. J. Phys. Chem. B 2009, 113, 5181.

(12) Xing, L. D.; Li, W. S.; Wang, C. Y.; Gu, F. L.; Xu, M. Q.; Tan, C. L.; Yi, J. J. Phys. Chem. B 2009, 113, 16596.

(13) Balakrishnan, P. G.; Ramesh, R.; Kumar, T. P. J. Power Sources 2006, 155,401 .

(14) Leising, R. A.; Palazzo, M. J.; Takeuchi, E. S.; Takeuchi, K. J. J. Power Sources 2001, 97, 681.

(15) Li, S. L.; Ai, X. P.; Feng, J. K.; Cao, Y. L.; Yang, H. X. J. Power Sources 2008, 184, 553.
(16) Xu, M. Q.; Xing, L. D.; Li, W. S.; Zuo, X. X.; Shu, D.; Li, G. L. J. Power Sources 2008, 184, 427.

(17) Chen, J.; Buhrmester, C.; Dahn, J. R. Electrochem. Solid-State Lett. 2005, 8, A59.

(18) Chen, Z. H.; Amine, K. Electrochim. Acta 2007, 53, 453.

(19) Taggougui, M.; Carré, B.; Willmann, P.; Lemordant, D. J. Power Sources 2007, 174, 1069.

(20) Wang, R. L.; Dahn, J. R. J. Electrochem. Soc. 2006, 153, A1922.

(21) Zheng, H. H.; Wang, X. J.; Li, B.; Qin, J. H. Chin. J. Power Sources 2006, 30, 511. [郑洪河, 王显军, 李 苞, 秦建华. 电 源技术, 2006, 30, 511.]

(22) Li, T. T.; Xing, L. D.; Li, W. S.; Peng, B.; Xu, M. Q.; Gu, F. L.; Hu, S. J. J. Phys. Chem. A 2011, 115, 4988.

(23) Demartinez, M. C.; Marquez, O. P.; Marquez, J.; Hahn, F.; Beden, B.; Crouigneau, P.; Rakotondrainibe, A.; Lamy, C. Syth. Met. 1997, 88, 187.

(24) Frisch, M. J.; Trucks, G. W.; Schlegel, H. B.; et al. Gaussian 03, Revision B.05; Gaussian Inc.: Pittsburgh, PA, 2003.

(25) Abbotto, A.; Streitwieser, A.; Schleyer, P. R. J. Am. Chem. Soc. 1997, 119, 11255.

(26) Wang, Y.; Balbuena, P. B. J. Phys. Chem. A 2001, 105, 9972.

(27) Tomasi, J.; Mennucci, B.; Cammi, R. Chem. Rev. 2005, 105, 2999.

(28) Trasatti, S. Pure Appl. Chem. 1986, 58, 955. 